ISSN 1392-3196 / e-ISSN 2335-8947

Zemdirbyste-Agriculture, vol. 106, No. 4 (2019), p. 345-350

DOI 10.13080/z-a.2019.106.044

\title{
The effect of the mycorrhization on the content of macroelements in the soil and leaves of blueberry cultivated after replantation
}

\author{
Zofia ZYDLIK, Piotr ZYDLIK, Tomasz KLEIBER \\ Poznań University of Life Sciences, Faculty of Horticulture and Landscape Architecture \\ Dąbrowskiego 159, Poznań, Poland \\ E-mail: zydlik@up.poznan.pl
}

\begin{abstract}
Research on the impact of the mycorrhization on the content of selected macroelements $(\mathrm{N}, \mathrm{P}, \mathrm{K}$ and $\mathrm{Mg}$ ) present in the soil and in the leaves of the highbush blueberry (Vaccinium corymbosum L.) cultivar 'Bluecrop' was carried out between 2009 and 2014. Plants were grown in the replanted soil (after 30 years of blueberry cultivation) and in the soil not used for blueberry cultivation (virgin soil). The mycorrhizal vaccine (mixture Vaccinium myrtillus L., $V$. vitis-idaea L. and Arctostaphylos uva-ursi L.) was used once when the plants were planted permanently. A varied effect of the use of mycorrhizal vaccine on the chemical composition of soil and plants was demonstrated. The application of this treatment significantly decreased the content of ammonium $\left(\mathrm{N}-\mathrm{NH}_{4}\right)$, phosphorus $(\mathrm{P})$ and potassium $(\mathrm{K})$ in the soil and increased nitrate $\left(\mathrm{N}_{-} \mathrm{NO}_{3}\right)$ and magnesium $(\mathrm{Mg})$ content in relation to the control treatment (without the mycorrhizal vaccine). Within the examined soils - soil after replantation as well as virgin soil - a significant effect of mycorrhizae on the increase of nitrogen $(\mathrm{N}), \mathrm{K}$ and $\mathrm{Mg}$ content in blueberry leaves was demonstrated.
\end{abstract}

Key words: arbuscular fungi, macroelements, replant disease, Vaccinium corymbosum.

\section{Introduction}

Perennial cultivation and planting of plants of the same species may lead to the phenomenon of soil exhaustion, which results in the so-called replant disease. The most common symptom of soil exhaustion are the reduction of nutrient content in the soil, disturbance of mineral balance and deterioration of soil structure, which may adversely affect the nutrition, growth and yield of plants (Zydlik, 2010; 2013). Plants susceptible to replant disease are less able to adapt to habitat conditions, which results in poor growth and yielding (Pacholak et al., 2009; Manici et al., 2013). The global area of blueberries grew by $65 \%$ from 2007 to 2014 (Brazelton, 2015). Poland is an important producer of blueberries in Europe. Due to the intensive production of this species, a number of its crops are exposed to the effects of replant disease. This is due to the frequent changes of highbush blueberry (Vaccinium corymbosum L.) planting resulting from the adaptation of its producers to the consumer requirements and changes in cultivation technology. For this reason, there is a need to conduct research on how to alleviate the effects of replant disease in the cultivation of this species.

One of the possibilities to alleviate the consequences of replant disease may be the use of a correctly selected mycorrhizal vaccine. In nature, there is a symbiotic relationship between higher plants and mycorrhizal fungi, which benefits both the fungi and the plants. Mycorrhizal fungi improve plant growth (Grzyb et al., 2015; Świerczyński et al., 2015), make it easier for plants to absorb difficult to access forms of phosphorus $(\mathrm{P})$ and nitrogen $(\mathrm{N})$ as well as transporting water and nutrients from the soil to the above-ground parts of the plants (Asrar et al., 2012; Ortas, 2012; Chatzistathis et al., 2013; Gamal et al., 2014). The mycorrhizal mechanism is based on the growth of the mycelium of the ericoid mycorrhiza in the intercellular space of the roots and on its external side, creating structures replacing root hairs that are missing in ericaceous (Ericaceae) plants, which include the highbush blueberry. Importantly, previous studies have shown that, as a result of mycorrhization, it is possible to improve plant resistance against biotic and abiotic stresses, including drought (Wu et al., 2013), salinity, temperature and acidity ( $\mathrm{pH})$ (PorrasSoriano et al., 2009), and resistance to diseases and pests (Schausberger et al., 2012; Torres-Vera et al., 2014). The positive effect of mycorrhiza on the growth, development and nutrition of plants from the Ericaceous family is particularly evident in soils with defective reaction, showing disturbances in chemical composition.

Please use the following format when citing the article:

Zydlik Z., Zydlik P., Kleiber T. 2019. The effect of the mycorrhization on the content of macroelements in the soil and leaves of blueberry cultivated after replantation. Zemdirbyste-Agriculture, 106 (4): 345-350. DOI 10.13080/z-a.2019.106.044 
The aim of the study was to assess the impact of the mycorrhization on the content of selected macroelements $(\mathrm{N}, \mathrm{P}, \mathrm{K}$ and $\mathrm{Mg}$ ) in the soil and leaves of the highbush blueberry (Vaccinium corymbosum L.) cultivar 'Bluecrop' grown in the replanted and virgin soil.

\section{Materials and methods}

Field experiment was carried out in 20092014 on the area of the Agricultural-Pomological Experimental Farm $\left(52^{\circ} 31^{\prime} \mathrm{N}, 16^{\circ} 38^{\prime} \mathrm{E}\right)$ in Przybroda, Poznań University of Life Science, Poland. Two soils were used: on the replanted soil (after 30 years of blueberry cultivation) and on the virgin soil previously not used for cultivation.

Two-year-old potted highbush blueberry (Vaccinium corymbosum L.) seedlings of the cultivar 'Bluecrop' were used in the experiment. The plants were planted at a spacing of $2.5 \times 1.5 \mathrm{~m}\left(2667\right.$ shrubs ha $\left.^{-1}\right)$. Immediately prior to being planted permanently, the root balls of the plants were soaked once in a mycorrhizal suspension. The vaccine was prepared in the Mykoflor Laboratory in Puławy, based on fungi isolated from roots of Vaccinium myrtillus L., V. vitis-idaea L. and Arctostaphylos uva-ursi L. that originated from Polish ecosystems. Distilled water $(500 \mathrm{ml})$ was added to the vaccine containing live mycelium and then mixed for 15 seconds. A suspension amounting to $1000 \mathrm{ml}$, in which blueberry seedlings were inoculated, was obtained.

Table 1. The meteorological conditions in 2009-2014

\begin{tabular}{|c|c|c|c|c|c|c|c|c|c|c|c|c|}
\hline \multirow{2}{*}{ Parameters } & \multicolumn{12}{|c|}{ Month } \\
\hline & 01 & 02 & 03 & 04 & 05 & 06 & 07 & 08 & 09 & 10 & 11 & 12 \\
\hline \multicolumn{13}{|c|}{ Precipitation in $\mathrm{mm}$} \\
\hline $\begin{array}{c}\text { Average of years } \\
1978-2007 \\
\end{array}$ & 29.2 & 26.3 & 36.1 & 30.0 & 45.5 & 64.5 & 77.9 & 59.6 & 45.2 & 34.1 & 35.1 & 42.7 \\
\hline $\begin{array}{c}\text { Average of years } \\
2009-2014\end{array}$ & 28.0 & 15.3 & 32.6 & 30.7 & 74.9 & 72.7 & 96.8 & 59.4 & 49.1 & 32.4 & 42.4 & 29.0 \\
\hline \multicolumn{13}{|c|}{ Temperature in ${ }^{\circ} \mathrm{C}$} \\
\hline $\begin{array}{c}\text { Average of years } \\
1978-2007\end{array}$ & -0.1 & -0.4 & 3.4 & 8.6 & 14.3 & 17.1 & 19.1 & 18.6 & 13.9 & 9.0 & 3.4 & 0.3 \\
\hline $\begin{array}{c}\text { Average of years } \\
2009-2014\end{array}$ & -2.8 & -0.6 & 3.48 & 9.41 & 13.9 & 17.2 & 19.9 & 22.1 & 14.2 & 8.6 & 5.3 & -0.5 \\
\hline
\end{tabular}

During the growing seasons of 2010, 2012 and 2014, soil samples (0-20 cm layer) were taken from the rows of bushes for chemical analyses. In the soil samples ammonium $\left(\mathrm{N}-\mathrm{NH}_{4}\right)$ and nitrate $\left(\mathrm{N}-\mathrm{NO}_{3}\right)$ contents were determined on the following dates: two weeks after the flowering of the bushes (spring period), after the intensive growth of the bushes (summer period) and at the end of the growing season (autumn period). $\mathrm{N}-\mathrm{NH}_{4}$ and $\mathrm{N}-\mathrm{NO}_{3}$ contents were determined on an ion chromatograph equipped with an isocratic pump and conductivity detector. Soil samples for other analyses $(\mathrm{pH}, \mathrm{P}, \mathrm{K}$ and $\mathrm{Mg}$ ) were taken after the intensive growth of the bushes in mid-July. The analyses were carried out using the following methods: $\mathrm{pH}$ in potassium chloride $(\mathrm{KCl})$ - potentiometric method, $\mathrm{P}$ and $\mathrm{K}$ - by the EgnerRiehm method, $\mathrm{Mg}$ - by the Schachtschabel method.

Representative leaf samples (200 leaves from a combination) were collected during mid-July at 2-year intervals (in 2010, 2012 and 2014 years). The harvested
Plants were grown in Endocalcaric Cambisol (sandy loam soil) (WRB, 2014) with a floatable fraction of $20 \%$ (sand with high loam content). The chemical composition of the soil (0-20 cm layer) at the start of the experiment was as follows (in $\mathrm{mg} 100 \mathrm{~g} \mathrm{~g}^{-1}$ dry matter (DM) soil): replantation: phosphorus (P) 5.66, potassium $(\mathrm{K})$ 9.10 and magnesium $(\mathrm{Mg}) 3.10$, acidity $(\mathrm{pH}) 3.98$; virgin soil: $\mathrm{P}$ 5.77, $\mathrm{K} 10.90$ and $\mathrm{Mg} 3.78, \mathrm{pH}$ 5.34. In order to lower the $\mathrm{pH}$ of unused soil, sulphur (S) was applied at a dose of $15 \mathrm{~g} \mathrm{~m}^{-2}$ before the commencement of the experiment. The reaction (in $1 \mathrm{M} \mathrm{KCl}$ ) of the soil in the tested sites was in the range $\mathrm{pH} 3.8-4.5$, as recommended for growing highbush blueberry (Pliszka, 2002).

The following combinations were tested: 1) replanted soil, 2) replanted soil with application of the mycorrhizal vaccine, 3) virgin soil and 4) virgin soil with application of the mycorrhizal vaccine. The experiment was replicated four times: the repeats were conducted on 10 shrubs, 4 combinations $\times 10$ shrubs $\times$ 4 repeats $=160$ plants.

During the spring season (March), nitrogen $(\mathrm{N})$ fertilization in a dose of $50 \mathrm{~kg} \mathrm{ha}^{-1} \mathrm{~N}$ with ammonium sulphate $\left(\left(\mathrm{NH}_{4}\right)_{2} \mathrm{SO}_{4}\right) 20 \% \mathrm{~N}$ and $24 \% \mathrm{~S}$ was used each year of the study. During the growing season, standard agrotechnical treatments recommended for highbush blueberry cultivation were used (Labanowska, Tartanus, 2017).

Recorded meteorological conditions (sum of precipitation and temperature) during the course of the study are described in Table 1. plant material was dried (at $45-50^{\circ} \mathrm{C}$ ), milled and then mineralised in the presence of sulphuric acid $\left(\mathrm{H}_{2} \mathrm{SO}_{4}\right)$ by means of Turbotherm mineralisation. The following chemical analyses were performed: $\mathrm{N}$ - Kjeldahl distillation method, P - Vanadate-molybdate method (Ostrowska et al., 1991), K, Ca, Mg - atomic absorption (AAS) with the apparatus Zeiss-Jena AAS-5 (Carl Zeiss Jena GmbH, Germany).

The results of chemical analyses of soil and leaves were analysed by variance using the program Statistica, version 13.1 (StatSoft Inc., USA). The significance of differences was assessed on the basis of Duncan's test at the significance level of $\alpha=0.05$.

\section{Results and discussion}

The replanted soil used in the study was characterised by poorer biological parameters when compared to virgin soil: less activity of soil enzymes 
(proteases and dehydrogenases), smaller numbers of proteolytic bacteria and significantly lower respiratory activity (Zydlik et al., 2016).

In this research, a significant effect of both the mycorrhizal vaccine and the examined sites on the chemical composition of the soil was demonstrated. After the mycorrhization both on the replanted and the virgin soil, the average content of $\mathrm{N}-\mathrm{NH}_{4}, \mathrm{P}$ and $\mathrm{K}$ significantly decreased (Tables 2, 4 and 5). This may have been due to their easier and more effective absorption of the relatively shallow blueberry root system by the colonised mycorrhizal fungi. In particular, this could refer to strong chemical absorption of $\mathrm{P}$, which under conditions of highly acidic and acidic soils is retro-gradated with iron $(\mathrm{Fe})$, manganese $(\mathrm{Mn})$ and aluminium $(\mathrm{Al})$.

Table 2. The influence of mycorrhization and soil type on the ammonium $\left(\mathrm{N}_{-} \mathrm{NH}_{4}\right)$ content $\left(\mathrm{mg} \mathrm{kg}^{-1} \mathrm{~g} \mathrm{DM}\right)$ in the soil

\begin{tabular}{cccccc}
\hline \multirow{2}{*}{ Type of soil } & \multirow{2}{*}{ Mycorrhyzation } & \multicolumn{3}{c}{ Years } & \multirow{2}{*}{ Average } \\
\cline { 3 - 5 } & & 2010 & 2012 & 2014 & \\
\hline \multirow{2}{*}{ Replanted } & - & $6.29 \mathrm{f}$ & $7.48 \mathrm{~g}$ & $0.74 \mathrm{a}$ & $4.84 \mathrm{D}$ \\
& + & $1.35 \mathrm{~b}$ & $1.60 \mathrm{c}$ & $0.61 \mathrm{a}$ & $1.19 \mathrm{~A}$ \\
\hline \multirow{2}{*}{ Virgin } & - & $2.57 \mathrm{e}$ & $1.85 \mathrm{c}$ & $0.75 \mathrm{a}$ & $1.72 \mathrm{C}$ \\
& + & $2.17 \mathrm{~d}$ & $1.76 \mathrm{c}$ & $0.58 \mathrm{a}$ & $1.51 \mathrm{~B}$ \\
\hline
\end{tabular}

Note. Means marked with the same small letter do not differ significantly at a $=0.05$; means marked with the same capital letter in columns do not differ significantly at $\mathrm{a}=0.05$.

Table 3. The influence of mycorrhization and soil type on the nitrate $\left(\mathrm{N}_{-} \mathrm{NO}_{3}\right)$ content $\left(\mathrm{mg} \mathrm{kg}^{-1} \mathrm{~g} \mathrm{DM}\right)$ in the soil

\begin{tabular}{cccccc}
\hline \multirow{2}{*}{ Type of soil } & \multirow{2}{*}{ Mycorrhyzation } & \multicolumn{3}{c}{ Years } & \multirow{2}{*}{ Average } \\
\cline { 3 - 5 } & & 2010 & 2012 & 2014 & \\
\hline \multirow{2}{*}{ Replanted } & - & $9,12 \mathrm{e}$ & $12.40 \mathrm{f}$ & $1.32 \mathrm{a}$ & $7.61 \mathrm{~B}$ \\
\hline \multirow{2}{*}{ Virgin } & + & $65.08 \mathrm{~h}$ & $12.52 \mathrm{f}$ & $9.91 \mathrm{e}$ & $29.17 \mathrm{D}$ \\
\hline
\end{tabular}

Explanation under Table 2

Table 4. The influence of mycorrhization and soil type on the phosphorus (P) content ( $\left.\mathrm{mg} \mathrm{kg}^{-1} \mathrm{~g} \mathrm{DM}\right)$ in the soil

\begin{tabular}{cccccc}
\hline \multirow{2}{*}{ Type of soil } & \multirow{2}{*}{ Mycorrhyzation } & \multicolumn{3}{c}{ Years } & \multirow{2}{*}{ Average } \\
\cline { 3 - 5 } & & 2010 & 2012 & 2014 & \\
\cline { 3 - 5 } Replanted & - & $5.66 \mathrm{e}$ & $5.69 \mathrm{e}$ & $4.74 \mathrm{c}$ & $5.37 \mathrm{C}$ \\
& + & $4.93 \mathrm{c}$ & $4.27 \mathrm{~b}$ & $4.82 \mathrm{c}$ & $4.67 \mathrm{~A}$ \\
\hline \multirow{2}{*}{ Virgin } & - & $5.77 \mathrm{e}$ & $4.18 \mathrm{~b}$ & $5.39 \mathrm{~d}$ & $5.11 \mathrm{~B}$ \\
& + & $5.91 \mathrm{e}$ & $4.09 \mathrm{~b}$ & $3.70 \mathrm{a}$ & $4.57 \mathrm{~A}$ \\
\hline
\end{tabular}

Explanation under Table 2

Table 5. The influence of mycorrhization and soil type on the potassium $(\mathrm{K})$ content $\left(\mathrm{mg} \mathrm{kg}^{-1} \mathrm{~g} \mathrm{DM}\right)$ in the soil

\begin{tabular}{cccccc}
\hline \multirow{2}{*}{ Type of soil } & \multirow{2}{*}{ Mycorrhyzation } & \multicolumn{3}{c}{ Years } & \multirow{2}{*}{ Average } \\
\cline { 3 - 5 } & & 2010 & 2012 & 2014 & \\
\cline { 3 - 5 } Replanted & - & $8.60 \mathrm{f}$ & $8.85 \mathrm{fg}$ & $4.60 \mathrm{c}$ & $7.35 \mathrm{C}$ \\
& + & $9.10 \mathrm{~g}$ & $4.20 \mathrm{~b}$ & $3.20 \mathrm{a}$ & $5.50 \mathrm{~A}$ \\
\hline \multirow{2}{*}{ Virgin } & - & $10.90 \mathrm{~h}$ & $8.70 \mathrm{f}$ & $4.40 \mathrm{bc}$ & $8.00 \mathrm{D}$ \\
& + & $7.00 \mathrm{e}$ & $8.55 \mathrm{f}$ & $5.20 \mathrm{~d}$ & $6.92 \mathrm{~B}$ \\
\hline
\end{tabular}

Explanation under Table 2

The conducted studies also showed that regardless of the soil type, the use of the mycorrhizal vaccine significantly increased the content of $\mathrm{N}-\mathrm{NO}_{3}$ and $\mathrm{Mg}$ in the soil (Tables 2 and 6). This can be accounted for by the positive impact of mycorrhizae on the activity of proteases in the soil (Zydlik et al., 2016). An increase of the dehydrogenases activity in the soil after using of a mycorrhizal vaccine was also recorded by Arriagada et al. (2012). These enzymes break down peptide bonds in proteins, causing their breakdown into free amino acids and dipeptides. The formation of these compounds from proteins enables their availability for microorganisms, which accelerates the decomposition of nitrogencontaining organic compounds. This may explain the increase in the content of $\mathrm{N}-\mathrm{NO}_{3}$ in the mycorrhizal soil.

Table 6. The influence of mycorrhization and soil type on the magnesium $(\mathrm{Mg})$ content $\left(\mathrm{mg} \mathrm{kg}^{-1} \mathrm{~g} \mathrm{DM}\right)$ in the soil

\begin{tabular}{cccccc}
\hline \multirow{2}{*}{ Type of soil } & \multirow{2}{*}{ Mycorrhyzation } & \multicolumn{3}{c}{ Years } & \multirow{2}{*}{ Average } \\
\cline { 3 - 5 } & & 2010 & 2012 & 2014 & \\
\hline \multirow{2}{*}{ Replanted } & - & $3.11 \mathrm{a}$ & $5.28 \mathrm{~d}$ & $4.73 \mathrm{c}$ & $4.37 \mathrm{~A}$ \\
& + & $3.11 \mathrm{a}$ & $6.66 \mathrm{f}$ & $4.78 \mathrm{c}$ & $4.82 \mathrm{~B}$ \\
\hline \multirow{2}{*}{ Virgin } & - & $3.79 \mathrm{~b}$ & $5.66 \mathrm{e}$ & $6.43 \mathrm{f}$ & $5.29 \mathrm{C}$ \\
& + & $5.28 \mathrm{~d}$ & $7.89 \mathrm{~g}$ & $6.66 \mathrm{f}$ & $6.61 \mathrm{D}$ \\
\hline
\end{tabular}

Explanation under Table 2 
In the conducted research, a significant influence of habitat conditions on the diversity of soil and contents of both nitrogen forms $\left(\mathrm{N}-\mathrm{NO}_{3}\right.$ and $\left.\mathrm{N}-\mathrm{NH}_{4}\right)$ was demonstrated. In the research, ammonium sulphate $\left(\left(\mathrm{NH}_{4}\right)_{2} \mathrm{SO}_{4}\right)$ was used in the initial fertilization, due to its acidifying effect on the soil. The highest nutritional needs for nitrogen highbush blueberry take place during the period between blooming and fruit ripening. Average

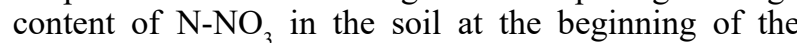
growing season was significantly higher than in the other examined dates (Table 7). Lowering the content of the $\mathrm{N}_{-} \mathrm{NO}_{3}$ anion in later periods of vegetation could be caused by its increased absorption by plant roots (this form of nitrogen is better absorbed by plants under acidic conditions), due to the lack of binding of nitrate ions through the soil sorption complex, which in the conditions found in our country has a negative charge or $\mathrm{N}-\mathrm{NO}_{3}$ leaching deep into the soil profile. In addition, under acidic conditions, the intensity of the nitrification process can be reduced.

Table 7. The average content ( $\left.\mathrm{mg} \mathrm{kg}^{-1} \mathrm{~g} \mathrm{DM}\right)$ of nitrate $\left(\mathrm{N}^{-\mathrm{NO}_{3}}\right)$ and ammonium $\left(\mathrm{N}_{-} \mathrm{NH}_{4}\right)$ ions taken from 2010,2012 and 2014 in the soil during different periods of vegetation

\begin{tabular}{|c|c|c|c|c|}
\hline Type of soil & Mycorrhyzation & Season & $\mathrm{N}-\mathrm{NO}_{3}$ & $\mathrm{~N}-\mathrm{NH}_{4}$ \\
\hline \multirow{6}{*}{ Replanted } & \multirow{3}{*}{-} & spring & $8.64 \mathrm{bcd}$ & $1.25 \mathrm{abc}$ \\
\hline & & summer & $3.22 \mathrm{ab}$ & $2.46 \mathrm{~cd}$ \\
\hline & & autumn & $1.26 \mathrm{a}$ & $0.93 \mathrm{ab}$ \\
\hline & \multirow{3}{*}{+} & spring & $11.01 \mathrm{~d}$ & $1.89 \mathrm{abc}$ \\
\hline & & summer & $3.39 \mathrm{ab}$ & $2.12 \mathrm{abcd}$ \\
\hline & & autumn & $2.38 \mathrm{a}$ & $0.74 \mathrm{a}$ \\
\hline \multirow{6}{*}{ Virgin } & \multirow{3}{*}{-} & spring & $8.93 \mathrm{~cd}$ & $3.46 \mathrm{~d}$ \\
\hline & & summer & $3.78 \mathrm{abc}$ & $2.49 \mathrm{~cd}$ \\
\hline & & autumn & $2.52 \mathrm{a}$ & $0.79 \mathrm{a}$ \\
\hline & \multirow{3}{*}{+} & spring & $10.24 \mathrm{~d}$ & $2.73 \mathrm{~cd}$ \\
\hline & & summer & $8.12 \mathrm{bcd}$ & $2.28 \mathrm{bcd}$ \\
\hline & & autumn & $4.68 \mathrm{abc}$ & $0.72 \mathrm{a}$ \\
\hline
\end{tabular}

Note. Explanation under Table 2; statistical analysis was made separately for each form of nitrogen.

In contrast to $\mathrm{N}_{-} \mathrm{NO}_{3}$, the marked $\mathrm{N}-\mathrm{NH}_{4}$ content was most often the highest in the middle of vegetation (Table 7). This mainly applies to the replanted soil. The differences in $\mathrm{N}-\mathrm{NH}_{4}$ content depending on the growing season were smaller on the virgin soil. One of the reasons for this could be climatic conditions: a higher sum of rainfall as well as a higher air temperature in the second half of the growing season as compared to the average values collected over many years (Table 1 ). The processes of nitrogen transformation in the soil, including its mineralisation, depend to a large extent on the temperature and humidity of the soil as well as content of nitrogen forms available to plants $\left(\mathrm{N}-\mathrm{NO}_{3}\right.$ and $\left.\mathrm{N}-\mathrm{NH}_{4}\right)$, which can vary during different seasons. A varied effect of the mycorrhization on the content of macronutrients in the soil was found to depend on the type of the tested site. The effects of using the mycorrhizal vaccine were most evident in the replanted soil. After its use, the content of $\mathrm{N}-\mathrm{NH}_{4} \mathrm{P}$ and $\mathrm{K}$ was 75,13 and $25 \%$ lower in relation to the soil, where mycorrhization was not applied (Tables 2, 4 and 5). The mentioned procedure carried out on the virgin soil caused a decrease in the content of these components by 12,11 and $13 \%$, respectively. The biggest changes occurred in the soil's content of $\mathrm{N}-\mathrm{NO}_{3}$. After mycorrhization, the content of this anion in the replanted soil increased almost four-fold, while in the virgin soil it was almost three-fold (Table 3).

An excess of this form of nitrogen may hinder the uptake of some microelements from the soil. The obtained results agree with the data reported by other authors regarding the increase in the effectiveness of mycorrhization applied under biotic stress conditions (lower enzymatic activity in replanted soil) or abiotic (low mineral content or low soil acidity) (Chen et al., 2017).

Leaf samples for chemical analyses were collected during the second half of July. Due to the fact that this is a period of stabilisation of vegetative growth, the second half of July is a term recommended for assessing the nutritional status of blueberries (Glonek, Komosa, 2013). As in the case of soil, a significant effect of the mycorrhizal vaccine on the chemical composition of highbush blueberry leaves was found. The facilitated absorption of macroelements by plants treated with the mycorrhizal vaccine is possible due to the production of a larger absorbent surface of the well-developed plant root system. This is particularly evident when compared to the root system of plants without this treatment (Raj, Sharma, 2009; Aka-Kacar et al., 2010). This symbiosis makes it possible to improve the conduction of nutrients and water (Asrar et al., 2012; Gamal et al., 2014).

In our studies, along with the use of mycorrhization, both on the replanted soil and on the virgin soil, the content of $\mathrm{N}, \mathrm{K}$ and $\mathrm{Mg}$ significantly increased in the leaves (Fig.). On the other hand, $\mathrm{P}$ content did not change. $\mathrm{N}, \mathrm{K}$ and $\mathrm{Mg}$ perform important physiological functions in the plant.

Nitrogen significantly affects the production of biomass; Mg affects the process of photosynthesis, while $\mathrm{K}$ regulates the plant's water management. It can therefore be assumed that the mycorrhization improved plant nutrition by means of these components. In combinations with the use of mycorrhizal vaccine the analyses indicate a decrease the content of majority macroelements in the soil. The obtained test results are similar to those generated in the previous studies on the content of $\mathrm{N}$ and P (Ortas et al., 2011; Gamal et al., 2014; Jiménez-Morenoa et al., 2018) both in the above-ground and underground parts of some mycorrhizal crops when compared to plants without this treatment.

The effect of the mycorrhization was more pronounced in the case of plants grown in replanted soil. An increase in the content of $\mathrm{N}$ and $\mathrm{Mg}$ in leaves (by $10 \%$ and $\approx 20 \%$, respectively) has been demonstrated. In the leaves of plants growing on the virgin soil, this increase amounted to $4 \%$ and $6 \%$, respectively. The $\mathrm{P}$ content did not vary. Hu et al. (2009) suggest that the effect of using mycorrhizal fungi decreases with the increase in the content of macroelements in the soil, especially that of $\mathrm{P}$. As determined in our research, the content of $\mathrm{N}$ in the leaves $(1.47-1.73 \% \mathrm{~N})$ was clearly smaller than those reported by other authors $(1.80-2.10 \% \mathrm{~N})$ (Pliszka, 2002). Likewise, when studying the effect of applying 

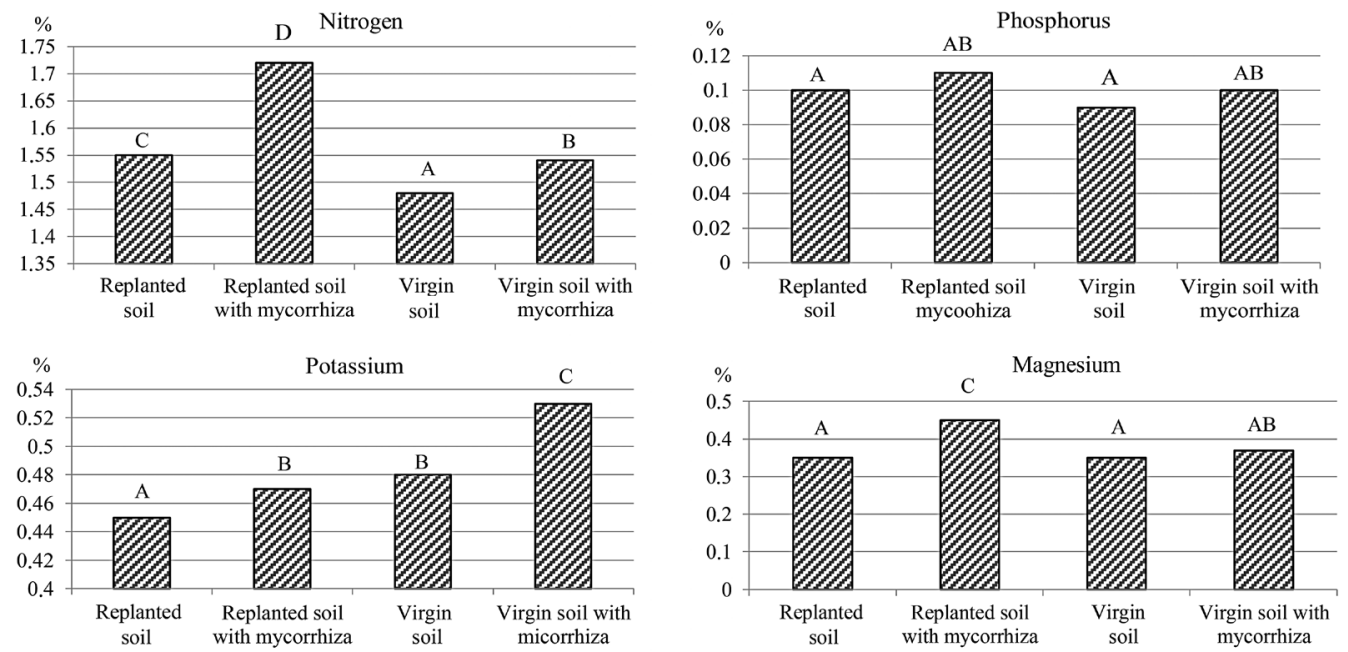

Note. Statistical analysis was made separately for each element; average numbers from the period between 2010-2014.

Figure. The content of macroelements (\% DM) in highbush blueberry leaves

fertigation in the cultivation of blueberries, Glonek and Komosa (2013) marked a higher average content of this element. The determined $\mathrm{P}$ contents, covering a range of $0.09-0.11 \% \mathrm{P}$, were, similarly to $\mathrm{N}$, lower than those (0.21-0.29\%) determined by Glonek and Komosa (2013).

Significant variation in the nutritional status of plants with $\mathrm{P}$ was demonstrated between the tested combinations. Equally significant changes occurred in the P content of the soil. Divergent views have been expressed in the scientific literature regarding the impact of P nutrition on its content in highbush blueberry leaves. In our research it was determined that the content of $\mathrm{K}$ in the leaves varied depending on the combination and covered the range (on average) of $0.45-0.53 \%$. In general, it can be concluded that the increase in $\mathrm{K}$ content in leaves positively correlated with the content of this component in the soil. The contents of $\mathrm{K}$ in leaves as determined in our studies was similar to those (0.49$0.52 \%$ ) reported by Glonek and Komosa (2013).

In contrast to the aforementioned macroelements the content of $\mathrm{Mg}(0.35-0.45 \%)$ was clearly greater than the ranges $(0.17-0.19 \%)$ given by Glonek and Komosa (2013). There was a tendency of the content of this component decreasing along with the increase in the content of $\mathrm{K}$ and calcium $(\mathrm{Ca})$.

\section{Conclusions}

1. In the combinations with the use of the mycorrhizal vaccine the content of ammonium ( $\left.\mathrm{N}-\mathrm{NH}_{4}\right)$, phosphorus $(\mathrm{P})$ and potassium $(\mathrm{K})$ dropped significantly in the soil with a simultaneous increase in nitrate $\left(\mathrm{N}-\mathrm{NO}_{3}\right)$ and magnesium $(\mathrm{Mg})$ content.

2. The effectiveness of the mycorrhizal vaccine varied depending on the soil. The influence of mycorrhizal fungi on the content of the studied nutrients in both soil and highbush blueberry leaves was more pronounced in the replanted soil than in the virgin soil.

3. By using the mycorrhization, the content of nitrogen $(\mathrm{N}), \mathrm{K}$ and $\mathrm{Mg}$ increased significantly in the leaves.

4. Application of the mycorrhizal vaccine improved the highbush blueberry nutrition with $\mathrm{N}, \mathrm{K}$ and $\mathrm{Mg}$, especially in the conditions of soil exhaustion.

Received 10082018

Accepted 09092019

\section{References}

1. Aka-Kacar Y., Akpinar C., Agar A., Yalcin-Mendi Y., Serge S., Orta I. 2010. The effect of mycorrhiza in nutrient uptake and biomass of cherry rootstocks during acclimatization. Romanian Biotechnological Letters, 15 (3): 5246-5252.

2. Arriagada C., Manquel D., Cornejo P., Soto J., Sampedro I., Ocampo J. 2012. Effects of the co-inoculation with saprobe and mycorrhizal fungi on Vaccinium corymbosum growth and some soil enzymatic activities. Journal of Soil Science and Plant Nutrition, 12 (2): 283-294. https://doi.org/10.4067/S0718-95162012000200008

3. Asrar A. A., Abdel-Fattach G. M., Elhindi K. M. 2012. Improving growth, flower yield and water relations of snapdragon (Antirhinum majus L.) plants grown under well-watered and water-stress conditions using arbuscular mycorrhizal fungi. Photosynthetica, 50: 305-316. https://doi.org/10.1007/s11099-012-0024-8

4. Brazelton C. 2015. World blueberry statistics and global market analysis. https://www.internationalblueberry.org/ downloads/world-blueberry-statistics-and-global-analysis2015-pdf-study-10/

5. Chatzistathis T., Orfanoudakis M., Aligragis D., Therios I. 2013. Colonization of Greek cultivars' root system by arbuscular mycorrhiza fungus: root morphology, growth, and mineral nutrition of olive plants. Scientia Agricola, 70 (3): 185-194.

https://doi.org/10.1590/S0103-90162013000300007

6. Chen W., Li J., Zhu H., Xu P., Chen J., Yao Q. 2017. The differential and interactive effects of arbuscular mycorrhizal fungus and phosphorus on the lateral root formation in Poncirus trifoliata (L.). Scientia Horticulturae, 217: 258-265. https://doi.org/10.1016/j.scienta.2017.02.008

7. Gamal M. A., Abdul-Wasea A. A., Salem M. A., Eslam M. A. 2014. Influence of arbuscular mycorrhiza and phosphorus fertilization on the gas exchange status, growth and nutrient contents of soybean (Glycine max. L) plants grown in a sandy loam soil. Journal of Fruit Agriculture and Environment, 12 (1): 150-156.

8. Glonek J., Komosa A. 2013. Fertigation of highbush blueberry (Vaccinium corymbosum L.). Part III. The effect on nutrient contents in leaves. Acta Scientiarum Polonorum, Hortorum Cultus, 12: 69-78.

9. Grzyb Z. S., Sas Paszt L., Piotrowski W., Malusa E. 2015. The influence of mycorrhizal fungi on the growth of apple and sour cherry maidens fertilized with different bioproducts in the organic nursery. Journal of Life Sciences, 9: $221-228$ 
10. Hu J., Ling X. G., Wang J. H., Dai J., Cu X. C., Chen R. R. Zhang J. B. 2009. Arbuscular mycorrhizal fungus enhances crop yield and P-uptake of maize (Zea mays L.): a field case study on a sandy loam soil as effected by long-term P-deficiency fertilization. Soil Biology and Biochemistry, 41: $2460-2465$.

https://doi.org/10.1016/j.soilbio.2009.09.002

11. Jiménez-Morenoa M. J., Moreno-Márqueza M. C., Moreno-Alíasb I., Rapoportb H., Fernández-Escobar R. 2018. Interaction between mycorrhization with Glomus intraradices and phosphorus in nursery olive plants. Scientia Horticulturae, 233: 249-255. https://doi.org/10.1016/j.scienta.2018.01.057

12. Łabanowska B. H., Tartanus M. (eds). 2017. Metodyka integrowanej produkcji borówki. Główny Inspektorat Ochrony Roślin i Nasiennictwa, Warszawa, Poland, 37 p. (in Polish).

13. Manici L. M., Keldererb M., Franke-Whittlec I. H., Rühmerd T., Baabe G., Nicoletti F., Caputoa F., Toppb A., Insamc H., Naeff A. 2013. Relationship between rootendophytic microbial communities and replant disease in specialized apple growing areas in Europe. Applied Soil Ecology, 72: 207-214. https://doi.org/10.1016/j.apsoil.2013.07.011

14. Ortas I. 2012. The effect of mycorrhizal fungal inoculation on plant yield, nutrient uptake and inoculation effectiveness under long-term field conditions. Field Crop Research, 125: 35-48. https://doi.org/10.1016/j.fcr.2011.08.005

15. Ortas I., Sari N., Akpinar Ç., Yetisir H. 2011. Screening mycorrhiza species for plant growth, $\mathrm{P}$ and $\mathrm{Zn}$ uptake in pepper seedling grown under greenhouse conditions. Scientia Horticulturae, 128: 92-98. https://doi.org/10.1016/j.scienta.2010.12.014

16. Ostrowska A., Gawliński S., Szczubiałka Z. 1991. Metody analizy i oceny właściwości gleb i roślin. Instytut Ochrony Środowiska. Warszawa, Poland, p. 245-279 (in Polish)

17. Pacholak E., Zydlik Z., Rutkowski K. 2009. Effect of 30year cultivation of apple trees on chemical and biochemical conditions of soil designed for replantation. Zeszyty Problemowe Postępów Nauk Rolniczych, 536: 161-168.

18. Pliszka K. 2002. Borówka wysoka. Warszawa, Poland, 170 p. (in Polish).
19. Porras-Soriano A., Soriano-Martín M. L., Porras-Piedra A., Azcón R. 2009. Arbuscular mycorrhizal fungi increased growth, nutrient uptake and tolerance to salinity in olive trees under nursery conditions. Journal of Plant Physiology, 166: $1350-1359$. https://doi.org/10.1016/j.jplph.2009.02.010

20. Raj H., Sharma S. D. 2009. Integration of soil solarization and chemical sterilization with beneficial microorganisms for the control of white root and growth of nursery apple. Scientia Horticulturae, 119: 126-131.

https://doi.org/10.1016/j.scienta.2008.07.025

21. Schausberger P., Peneder S., Jürschik S., Hoffmann D. 2012. Mycorrhiza changes plant volatiles to attract spider mite enemies. Functional Ecology, 26 (2): 441-449. https://doi.org/10.1111/j.1365-2435.2011.01947.x

22. Świerczyński S., Stachowiak A., Golcz-Polaszewska M. 2015. Maiden pear trees growth in replant soil after inoculation of rootstocks with mycorrhizal inoculum. Nauka Przyroda Technologia, 9 (1): \#3. https://doi.org/10.17306/J.NPT

23. Torres-Vera R., García J. M., Pozo M. J., López-Ráez J. A. 2014. Do strigolactones contribute to plant defence? Molecular Plant Pathology, 15 (2): 211-216. https://doi.org/10.1111/mpp.12074

24. WRB. 2014. World reference base for soil resources. World Soil Resources Reports No. 106. FAO, p. 187-189. https://doi.org/10.1016/j.scienta.2013.09.010

25. Wu Q. S., Srivastava A. K., Zou Y. N. 2013. AMF-induced tolerance to drought stress in citrus: a review. Scientia Horticulturae, 164: 77-87.

26. Zydlik Z. 2010. Microbiological and biochemical properties and growth and yielding of apple trees after repalntation. Rozprawy Naukowe. Uniwersytet Przyrodniczy w Poznaniu, 412: 1-100 (in Polish).

27. Zydlik Z. 2013. Effect of biological preparations on the growth of strawberries cultivated in a sick soil. Electronical Journal of Polish Agricultural Universities. Horticulture, 16 (4): 9.

28. Zydlik Z., Pacholak E., Rutkowski K., Styla K., Zydlik P. 2016. The influence of a mycorrhizal vaccine on the biochemical properties of soil in the plantation of blueberry. Zemdirbyste-Agriculture, 103 (1): 61-66. https://doi.org/10.13080/z-a.2016.103.008

\title{
Mikorizacijos įtaka makroelementų kiekiui dirvožemyje ir šilauogių lapuose, jas auginant pakartotinai toje pačioje vietoje
}

\author{
Z. Zydlik, P. Zydlik, T. Kleiber
}

Poznanės gyvybės mokslų universiteto Sodininkystès, daržininkystės ir landšafto architektūros fakultetas, Lenkija

\begin{abstract}
Santrauka
Mikorizacijos įtaka makroelementų N, P, K ir Mg kiekiui dirvožemyje ir aukštosios šilauogès (Vaccinium corymbosum L.) veislès 'Bluecrop' lapuose buvo tirta 2009-2014 m. Augalai auginti dirvožemyje, kuriame šilauogès buvo augintos 30 metų, ir dirvožemyje, kuriame jos anksčiau neaugo. Mikorizès vakcina (Vaccinium myrtillus L., V. vitis-idaea L. ir Arctostaphylos uva-ursi L. mišinys) buvo panaudota vieną kartą, kai augalai buvo sodinami ilgam laikui. Tyrimo metu nustatytas įvairus mikorizès vakcinos poveikis dirvožemio cheminei sudéčiai ir augalams. Panaudojus šią vakciną, dirvožemyje reikšmingai sumažėjo amonio azoto $\left(\mathrm{N}_{-} \mathrm{NH}_{4}\right)$, fosforo $(\mathrm{P})$ bei kalio $(\mathrm{K})$ ir padidejo nitratų azoto $\left(\mathrm{N}-\mathrm{NO}_{3}\right)$ bei magnio $(\mathrm{Mg})$ kiekiai, palyginus su kontroliniu variantu, kuriame mikorizès vakcina nebuvo naudota. Reikšminga mikorizès vakcinos įtaka N, K ir Mg kiekiui šilauogiu lapuose buvo nustatyta abiejuose dirvožemiuose: ir kuriame šilauogès buvo augintos, ir kuriame neaugo.
\end{abstract}

Reikšminiai žodžiai: arbuskuliariniai grybai, atsodinimo liga, makroelementai, Vaccinium corymbosum. 